\title{
HERITABILITY, VARIABILITY, GENETIC CORRELATION AND PATH ANALYSIS FOR QUANTITATIVE TRAITS IN DURUM AND BREAD WHEAT UNDER DRY FARMING CONDITIONS
}

Ismail Hussain Ali

College of Agriculture

University of Salahaddin/Erbil
Erfan Fateh Shakor

Directorate of Agricultural Researches

Ministry of Agriculture/Erbil

\begin{abstract}
Two field experiments were carried out during the 2009-2010 growing season at the station of Directorate of Agricultural Researches/Erbil under dry farming conditions. The first experiment included 25 strains of durum wheat, and the second included 20 strains of bread wheat. Growth trait, yield and its components were studied, and then data are entered in the statistical genetic analysis, as well as the path coefficient analysis. The results showed high genetic variation, heritability and genetic advance for plant height, number of spikes, 1000 grain weight, biological yield and grain yield in durum wheat. While it was high in all traits in bread wheat. The grain yield was correlated genetically positive and significantly with 1000 grain weight, biological yield and harvest index in durum wheat, while showed genetically positive and significant correlation with all traits in bread wheat. The path coefficient analysis revealed that harvest index and biological yield had the maximum positive direct effects on grain yield in durum wheat reached 0.966 and 0.242 , respectively. While the harvest index had the maximum positive direct effect (1.417) on grain yield in bread wheat, which was used as a criterion for the selection of superior genotypes in each group.
\end{abstract}

\section{INTRODUCTION}

The grain yield is a complex traits which is influenced by many factors, would be plant breeders interested to know the nature of the relationship and the kind between these traits, especially under dry farming conditions, where the water is the main limiting factor in many areas of wheat production around the world due to uneven rainfall distribution during the growing season, so it is important that characterized cultivars cultivated in these areas in the superior performance of grain yield and its components under the limited and non-limited of moisture conditions (Okuyama et al., 2004). Grain yield is the result of many developmental and physiological events that occur during the life cycle of the plant, and grain yield is determined by three main components; the number of spikes/plant, number of grain/spike and weight of grains (Poehlman, 1987). Hochman (1982) and McMaster et al. (1984) referred that the influence of each one of these components on the product of grain depends on the stage of growth that occurs due to water deficit. At elongation stage, the inadequate availability of water or rain affect on the components of grain yield by increasing the number of spikes/plant, grains/spike, and weight of grains/plant, while leading to increased weight of grains during the grain filling stage (McMaster et al.,1984). Simane et al. (1993) reported high correlation between the number of grains/spike and grain yield along the span of

Recived 15/3/2011 accepted $10 / 10 / 2011$. 
water stress. The wheat plants are more sensitive to water stress between the two phases (booting stage) and (grain filling) as compared to all other periods (Fisher et al., 1977 and Hochman, 1982). On the other hand, avoiding of wheat plants to water stress during the tillering and elongation stages is more important than the flowering and grain filling stages (Thompson and Chase, 1992).

The breeding program for higher yield depends on the estimation of genetic variability, heritability, genetic advance and the correlations between yield and its components, but it is not sufficient to understand the importance of each one of these components in determining the grain yield (Dewey and Lu, 1959). Path analysis is a standarized partial regression coefficient that measures the direct influence of one variable upon another, it also provides a means of partitioning both direct and indirect effects and effectively measuring the relative importance of causal factors, which, helps to build an effectively selection program. Using this method (Kumar and Hunshal, 1998) observed that the harvest index, biomass yield, spikes/plant and grains/spike had most important direct effects on the grain yield. Under the water deficit conditions, but a long period of grain filling Simane et al.(1998) found high correlation between drought tolerance and spikes $/ \mathrm{m}^{2}$ and grains/spike. Yagdi (2009) found that the 1000 grain weight have high direct effect on grain yield. This research aims to estimates heritability, genetic variation and genetic correlation between different quantitative traits in a number of strains selected from durum and bread wheat, and then to identify the most important traits of a direct effect on the grain yield to be adopted as a criterion for selection.

\section{MATEREALS AND METHODES}

Two field experiments were carried out separated during the season 20092010 at the research station of the Directorate of Agricultural Research in the area of Ainkawa in Erbil/Kurdistan region of Iraq under the circumstances amounted to rain $(315 \mathrm{~mm})$ with good distribution depend on meteorological in the search site. The first experiment included 25 advanced strains of durum wheat (Triticum durum Desf.), and second included 20 advanced strains of bread wheat (Triticum aestivum L.) (Table, 1) was originally selected (on the basis of phenotypic characteristics and grain yield in the nursery of the observations had been planted during the season 2008-2009) of 57 and 67 advanced strain of two types, respectively. Each experiment was carried out according to randomized complete block design with three replicates and each experimental unit included a one row of each one of genotype. The grains were dibbled in rows (using $120 \mathrm{~kg} / \mathrm{ha}$ seeding rate) keeping between row distances at $20 \mathrm{~cm}$. Single row of $2.5 \mathrm{~m}$ length served as an experimental unit. Conducted service operations of soil and crop, and when plants reached the flowering stage, were recorded the flag leaf area of mother shoot according to formula (leaf length $\times$ width $\times 0.95$ ) (Thomas, 1975), and at maturity data were recorded for plant height $(\mathrm{cm})$, then harvested plants of each line as a whole to calculate biomass yield ( $t / h a)$, grain yield ( $t / h a)$, harvest index, spike Genetic statistical analysis for all the traits studied were computed, then the estimates of genetic variation, heritability and coefficints of genetic correlation between traits were done by the components of expected mean squares from 
Table (1): Pedigree of durum and bread wheat strains used in the study.

\begin{tabular}{|c|c|c|c|c|c|}
\hline \multicolumn{6}{|c|}{ Durum wheat } \\
\hline No. & $\mathrm{Ig}$ & crop & pop type & \multicolumn{2}{|c|}{ Selection } \\
\hline 1 & 114239 & ICDW & UM & \multicolumn{2}{|c|}{ ICD86-0471-ABL-0TR-8AP-0TR-20AP-0TR } \\
\hline 2 & 114251 & ICDW & UM & \multicolumn{2}{|c|}{ ICD85-1340-ABL-6AP-0TR } \\
\hline 3 & 114262 & ICDW & UM & \multicolumn{2}{|c|}{ ICD85-0641-ABL-6AP-0TR-2AP-0TR-4AP-0TR } \\
\hline 4 & 114293 & ICDW & UM & \multicolumn{2}{|c|}{ ICD84-0322-7AP-TR-20AP-0TR } \\
\hline 5 & 114300 & ICDW & UM & \multicolumn{2}{|c|}{ ICD83-0050-4AP-14AP-TR-3AP-0TR } \\
\hline 6 & 114322 & ICDW & UM & \multicolumn{2}{|c|}{ ICD78-0064-19AP-4AP-1AP-1AP-1AP-0SH } \\
\hline 7 & 114326 & ICDW & UM & \multicolumn{2}{|c|}{ ICD-BM-ABL-413-0AP } \\
\hline 8 & 114347 & ICDW & UM & \multicolumn{2}{|c|}{ CD 523-3Y-1Y-2M-0Y } \\
\hline 9 & 114385 & ICDW & UM & \multicolumn{2}{|c|}{ 12938-5L-1AP-1AP-4AP-0AP } \\
\hline 10 & 129068 & ICDW & UM & \multicolumn{2}{|c|}{ ICD86-0041-ABL-13AP-0TR-7AP-0TR } \\
\hline 11 & 129076 & ICDW & UM & \multicolumn{2}{|c|}{ ICD88-1233-ABL-8AP-0AP-6AP-0AP } \\
\hline 12 & 139248 & ICDW & $\mathrm{CV}$ & \multicolumn{2}{|c|}{ ICD78-0030-2AP-2AP-3AP-2AP-0AP } \\
\hline 13 & 139250 & ICDW & $\mathrm{CV}$ & \multicolumn{2}{|c|}{ CD 20632-2AP-3AP-0AP } \\
\hline 14 & 139251 & ICDW & $\mathrm{CV}$ & \multicolumn{2}{|c|}{ CD 39513-12AP-3AP-0AP } \\
\hline 15 & 139252 & ICDW & $\mathrm{CV}$ & \multicolumn{2}{|c|}{ ICD79-0852-13AP-3AP-2AP-0AP } \\
\hline 16 & 139253 & ICDW & $\mathrm{CV}$ & \multicolumn{2}{|c|}{ ICD79-1463-1AP-2AP-2AP-1AP-0SH } \\
\hline 17 & 139255 & ICDW & $\mathrm{CV}$ & \multicolumn{2}{|c|}{ ICD85-0642-ABL-28AP-0TR-2AP-0TR } \\
\hline 18 & 139256 & ICDW & $\mathrm{CV}$ & \multicolumn{2}{|c|}{ ICD89-0263-AL-4AP-0AP-6AP-0AP } \\
\hline 19 & 139258 & ICDW & $\mathrm{CV}$ & \multicolumn{2}{|c|}{ ICD91-0083-AB-1AP-0AP-5AP-0AP } \\
\hline 20 & 139259 & ICDW & $\mathrm{CV}$ & \multicolumn{2}{|c|}{ ICD91-0811-AB-3AP-0AP-2AP-0AP } \\
\hline 21 & 139262 & ICDW & $\mathrm{CV}$ & ICD8s & -6AP-0AP \\
\hline 22 & 139263 & ICDW & $\mathrm{CV}$ & ICD91 & -12AP-0AP \\
\hline 23 & 139264 & ICDW & $\mathrm{CV}$ & ICD91 & P-1AP-0AP \\
\hline 24 & 139265 & ICDW & $\mathrm{CV}$ & ICD92 & AP-7AP-0TR \\
\hline 25 & simeto & check & & & \\
\hline & & & & ead $w$ & \\
\hline No. & $\mathrm{Ig}$ & crop & pop type & Or I & province \\
\hline 1 & 41587 & ICBW & LA & PAK & Baluchistan \\
\hline 2 & 41668 & ICBW & LA & PAK & Baluchistan \\
\hline 3 & 41675 & ICBW & LA & PAK & Baluchistan \\
\hline 4 & 41680 & ICBW & LA & PAK & Baluchistan \\
\hline 5 & 41762 & ICBW & LA & PAK & Baluchistan \\
\hline 6 & 41772 & ICBW & LA & PAK & Baluchistan \\
\hline 7 & 41946 & ICBW & $\mathrm{CV}$ & MAR & Ten sift \\
\hline 8 & 43244 & ICBW & LA & PAK & Baluchistan \\
\hline 9 & 43252 & ICBW & LA & PAK & Baluchistan \\
\hline 10 & 43257 & ICBW & LA & PAK & Baluchistan \\
\hline 11 & 44266 & ICBW & LA & TUN & Safaqis [Sfax] \\
\hline 12 & 94857 & ICBW & LA & TUN & Safaqis [Sfax] \\
\hline 13 & 94867 & ICBW & LA & TUN & Safaqis [Sfax] \\
\hline 14 & 115798 & ICBW & LA & JOR & Az Zarqa \\
\hline 15 & 122110 & ICBW & LA & IRN & Tehran \\
\hline 16 & 138362 & ICBW & LA & TKM & Ashkhabad \\
\hline 17 & 138388 & ICBW & LA & SYR & Damascus \\
\hline 18 & 138841 & ICBW & LA & IRN & Khorasan \\
\hline 19 & 138888 & ICBW & LA & AFG & Samangan \\
\hline 20 & cham-6 & check & & & \\
\hline
\end{tabular}

length $(\mathrm{cm})$ and the components of grain yield [number of spikes $/ \mathrm{m}^{2}$, number of grains/spike and 1000 grain weight $(\mathrm{g})]$. 

below:

analysis of variance and covariance between traits were estimated as the

\begin{tabular}{|c|c|c|c|}
\hline S.O.V. & $(\mathrm{EMS}) \mathrm{xx}$ & $(\mathrm{EMCP}) \mathrm{xy}$ & $(\mathrm{EMS}) \mathrm{yy}$ \\
\hline Genotypes & $\sigma^{2} E_{x}+r \sigma^{2} G_{x}$ & $\sigma E_{x} E_{y}+r \sigma G_{x} G_{y}$ & $\sigma^{2} E_{y}+r \sigma^{2} G_{y}$ \\
\hline Error & $\sigma^{2} E_{x}$ & $\sigma E_{x} E_{y}$ & $\sigma^{2} E y$ \\
\hline
\end{tabular}

Genotypic $\left(\sigma^{2} G\right)$, Phenotypic $\left(\sigma^{2} P\right)$ and environment variance $\left(\sigma^{2} E\right)$ were estimated according to the following formula (Walter, 1975), using the Excel program.

$$
\sigma^{2} G=\frac{M S G-M S E}{r} \quad \sigma^{2} E=M S E \quad \sigma^{2} P=\sigma^{2} G+\sigma^{2} E
$$

Variance of $\sigma^{2} G$ and $\sigma^{2} E$ was estimated by applying the following two equations (Kempthorne, 1969):

$$
V\left(\sigma^{2} G\right)=\frac{2}{r^{2}}\left[\frac{(M S G)^{2}}{(K+2)}+\frac{(M S E)^{2}}{(K+2)}\right] \quad V\left(\sigma^{2} E\right)=\frac{2(M S E)^{2}}{K+2}
$$

While the variance of $\sigma^{2} P$ has been estimated by applying the following formula (Mather and Jinks, 1982):

$$
V\left(\sigma^{2} P\right)=\frac{2\left(\sigma^{2} P\right)^{2}}{N}
$$

Where $\mathrm{r}$ is the number of replicates; $\mathrm{N}$ is the sum of degrees of freedom for genotypes, and the experimental error; $\sigma G_{x} G_{y}$ is the genetic covariance between $\mathrm{x}$ and y traits.

Taking the square root of the variations above we then get the standard error $(S E)$ for each variance for the test of significant of each one of these variances using statistical t-test. Genetic coefficient of variation $(G C V \%)$ and genetic correlation $(r G)$ were estimated by the following equations:

$$
G C V \%=\sqrt{\sigma^{2} G} / \bar{X}
$$

$$
r G=\sigma G_{x} G_{y} / \sqrt{\sigma^{2} G_{x}} \cdot \sigma^{2} G_{y}
$$

Heritability in the broad sense estimated by using the equation: $H_{\text {B.S. }}^{2}=\sigma^{2} G / \sigma^{2} P$, and Expected genetic advance by formula: $E G A=H_{\text {B.S. }}^{2} \sigma P$, as well as the expected genetic advance for the mean were calculated by the equation: $E G A \%=G A / \bar{X} .100$, where $\mathrm{K}$ is the degrees of freedom for each source of variation; and $\sigma P$ is the phenotypic standard deviation, and $\mathrm{i}$ is constant $(k=1.76)$, at $10 \%$ selection intensity.

Path coefficient analysis was performed as described by (Dewey and Lu, 1959). Grain yield was kept as resultant variable and other traits as causal ones.

Estimation of the path coefficients (direct effects) for the independent variables in the depend variable (grain yield) using the genetic correlation matrix, and a linear equation is represented:

$Y i=p_{1} y X_{1}+p_{2} y X_{2}+\ldots \ldots \ldots \ldots . .+e$, and then the normal equation is: $R\lfloor\underline{p}\rfloor=[\underline{r}]$ 
$\therefore[\underline{p}]=[R]^{-1}[\underline{r}]$, where: $\lfloor\underline{p}]=$ vector of path coefficients; $[R]^{-1}=$ matrix inverse of genetic correlation coefficients between the independent variables (causal). $[\underline{r}]=$ vector of genetic correlation coefficients between the independent variables and the dependent variable.

\section{1: Durum wheat.}

\section{RESULTS AND DISCUSSION}

a - The performance of genotypes and phenotypic differences: Table (2) shows the means of 25 genotypes of durum wheat, which differed in all the studied traits, according to analysis of variance and $\mathrm{F}$ values (Table, 3 ). Genotype 1 was superior in spike length $(7 \mathrm{~cm}), 1000$ grain weight $(51.7$ grams $)$, grain yield $(6.49 \mathrm{t} / \mathrm{ha})$ and harvest index $(0.51)$. The genotypes 7 shows superiority in plant height $(108.7 \mathrm{~cm})$; 25 in the flag leaf area $\left(47.33 \mathrm{~cm}^{2}\right) ; 6$ in the number of spikes $/ \mathrm{m}^{2}$ (348 spikes); 19 and 21 in biomass yield (13.44 t/ha). The results shows existence of a wide range of genetic variation between the genotypes in most of the traits as reflected through the values of genetic variability, which reached the high significant in plant height, number of spikes $/ \mathrm{m}^{2}, 1000$ grain weight, biomass yield and grain yield, which were (91.9, 1395.6, 21.0, 1.67 and 0.98 respectively) and this was reflected high-contrast positive and that higher values of heritability of these traits, which were high, reached $82.53 \%$ for plant height and $74 \%$ of the 1000 grain weight and medium to the number of spikes $/ \mathrm{m}^{2}$, biomass yield and grain yield, which means little affected by the environment in time which decreased the heritability of the other traits which was very affected by the environment as is evident in the high variability of environmental values of these traits more than the traits which gave high and medium heritability values. The high values of genetic variation in these traits led to an increase in the values of phenotypic variation and heritability, which led eventually to the lifting of the values of expected genetic advance, amounted to 18.0 $\mathrm{cm}$ for plant height, $49.5 \mathrm{spike} / \mathrm{m}^{2}, 5.18 \mathrm{~g}$ of the 1000 grain weight, $1.62 \mathrm{t} / \mathrm{ha}$ for biomass yield and $1.31 \mathrm{t} /$ ha for grain yield (Table, 3 ).

b - Genetic correlation and path coefficient analysis: Data presented in Table (4) are the values of genetic correlation coefficients between traits and it notes the existence of a negative correlation or weak between plant height and other traits. Flag leaf area showed high positive genetic correlation and significantly with spike length, number of spikes $/ \mathrm{m}^{2}$ and the number of grains/spike, but weak or negative with other traits. Spike length show significantly negative genetic correlation with the number of spikes $/ \mathrm{m}^{2}$, and weak or negative with other traits. The genetic correlation between the number of spikes $/ \mathrm{m}^{2}$ and the biomass yield is positive and significant, while weak or negative with the other traits. The number of grains/spike shows genetically positive correlation but not significant with harvest index, grain yield, biomass yield and 1000 grain weight, while the genetic correlation between 1000 grain weight and harvest index, grain yield and biomass yield is positive and significant, as well as among grain yield, biomass yield and harvest index. It is noted here also appears positive genetic correlation between grain yield and its components and the same ingredients except for the negative and weak genetic correlation between the numbers of spikes $/ \mathrm{m}^{2}$ and 1000 grain weight, 
Table (2) Mean of the studied traits in durum wheat genotypes.

\begin{tabular}{|c|c|c|c|c|c|c|c|c|c|}
\hline Genotypes & $\begin{array}{c}\text { PH } \\
(\mathrm{cm})\end{array}$ & $\begin{array}{c}\text { FLA } \\
\left(\mathrm{cm}^{2}\right)\end{array}$ & $\begin{array}{c}\text { SL } \\
(\mathrm{cm})\end{array}$ & SN/m & G/S & $\begin{array}{c}1000 \\
\text { GW } \\
(\mathrm{g})\end{array}$ & $\begin{array}{c}\text { BY } \\
(\mathrm{t} / \mathrm{ha})\end{array}$ & $\begin{array}{c}\mathrm{GY} \\
(\mathrm{t} / \mathrm{ha})\end{array}$ & $\begin{array}{c}\mathrm{HI} \\
(\%)\end{array}$ \\
\hline 1 & 82.3 & 43.33 & 7 & 225 & 36.33 & 51.7 & 12.78 & 6.49 & 0.51 \\
\hline 2 & 92.7 & 33.33 & 7 & 251.33 & 35 & 42.1 & 11.58 & 4.02 & 0.35 \\
\hline 3 & 100 & 33 & 467 & 343 & 34.67 & 38.17 & 13.19 & 6.35 & 0.48 \\
\hline 4 & 98.7 & 33.67 & 6.67 & 230 & 27 & 37.3 & 8.03 & 1.93 & 0.27 \\
\hline 5 & 100 & 24.67 & 6.67 & 292 & 27.67 & 45.77 & 11.92 & 5.44 & 0.45 \\
\hline 6 & 77 & 29.33 & 6.67 & 348 & 36.33 & 36.76 & 11.58 & 2.82 & 0.24 \\
\hline 7 & 108.7 & 39 & 6.67 & 188.67 & 39.33 & 32.8 & 8.39 & 2.76 & 0.31 \\
\hline 8 & 81.3 & 34.33 & 6 & 230.33 & 35.33 & 45.23 & 12.25 & 5.52 & 0.46 \\
\hline 9 & 85.3 & 33 & 7 & 251 & 36 & 44.9 & 11.28 & 4.86 & 0.44 \\
\hline 10 & 77.67 & 43.33 & 6 & 249 & 36.67 & 47.37 & 12.08 & 3.76 & 0.31 \\
\hline 11 & 90.67 & 38.67 & 7 & 270.33 & 36.33 & 40.67 & 12.08 & 5.51 & 0.46 \\
\hline 12 & 86.67 & 41.33 & 6.67 & 282.33 & 32.33 & 40.17 & 11.72 & 5.19 & 0.44 \\
\hline 13 & 86.67 & 38 & 7 & 253.67 & 35 & 34.37 & 10.94 & 3.63 & 0.33 \\
\hline 14 & 86.33 & 40 & 7 & 217.67 & 40.33 & 45.57 & 10.56 & 4.27 & 0.42 \\
\hline 15 & 77 & 43 & 6.67 & 285 & 27.33 & 42.43 & 11.94 & 5.18 & 0.43 \\
\hline 16 & 80 & 33 & 6.33 & 270.33 & 29 & 39.50 & 11.69 & 4.78 & 0.41 \\
\hline 17 & 104.67 & 41.33 & 6.33 & 192.67 & 29.33 & 32.17 & 7.50 & 2.40 & 0.32 \\
\hline 18 & 87.33 & 36 & 6 & 283.33 & 33 & 38.43 & 11.69 & 4.33 & 0.37 \\
\hline 19 & 88.67 & 35.67 & 6.33 & 307.33 & 36.33 & 40.50 & 13.44 & 4.90 & 0.37 \\
\hline 20 & 82 & 33.33 & 6.33 & 235.67 & 31.67 & 38.13 & 10.06 & 3.08 & 0.31 \\
\hline 21 & 91.67 & 31 & 6.67 & 298.33 & 33 & 43.17 & 13.44 & 5.11 & 0.39 \\
\hline 22 & 96.33 & 32.67 & 6 & 344.67 & 32.33 & 40.8 & 12.94 & 3.76 & 0.29 \\
\hline 23 & 94.33 & 37.67 & 6 & 296.33 & 32.67 & 41.13 & 12.53 & 4.39 & 0.35 \\
\hline 24 & 65.67 & 39.33 & 6.67 & 333.67 & 37 & 32.06 & 13.39 & 2.92 & 0.23 \\
\hline 25 & 80 & 47.33 & 7 & 234.33 & 39.33 & 40.03 & 12.44 & 3.92 & 0.32 \\
\hline LSD $(5 \%)$ & $\mathbf{7 . 2 0}$ & $\mathbf{1 1 . 8 0}$ & $\mathbf{1 . 0 0}$ & $\mathbf{7 2 . 6 3}$ & $\mathbf{4 . 3 5}$ & $\mathbf{2 . 7 3}$ & $\mathbf{2 . 7 2}$ & $\mathbf{1 . 9 3}$ & $\mathbf{0 . 1 5}$ \\
\hline
\end{tabular}

$\mathrm{PH}=$ Plant height; FLA = Flag leaf area; $\mathrm{SL}=$ Spike length; $\mathrm{SN} / \mathrm{m}^{2} ; \mathrm{G} / \mathrm{S}=$ Number of grains/spike; $1000 \mathrm{GW}=1000$ grain weight; $\mathrm{By}=$ Biomass yield; $\mathrm{GY}=$ Grain yield; $\mathrm{HI}=$ Harvest index.

that is in agree with (Sinha et al., 1984, Ali, 1995, Ozkan et al., 1997, Nofouzi et al., 2008 and Talebi et al., 2011). These results in terms of the positive genetic correlation between grain yield and many traits that have direct relevance to its components like biomass yield and harvest index an important indicator of the reliability of the selection for high grain yield on any of these traits. It has been followed up on these positive results of the path coefficient analysis which the results had described in Table (5), as a result of the high and positive genetic correlation between harvest index and grain yield (0.977) is higher positive direct effect of harvest index on grain yield (0.966), followed by the positive direct effect of the biomass yield $(0.242)$ resulting from the high positive correlation between them (0.776). These positive correlations led to show the positive indirect effect for each of these two traits through the other on grain yield (0.542 and 0.136) 
respectively, while the result of positive genetic correlation between 1000 grain weight and grain yield (0.849) have a negative direct effect of 1000 grain weight on grain yield (-0.116), but showed the highest positive indirect effect through harvest index, and this underlines the lack of necessity for the status of the positive genetic correlation with grain yield direct effect positively upon this supports the findings of the many researchers (Garcia del Moral et al ., 2003 and Bhutta et al., 2005). While the other traits showed negative or weak direct and indirect effects. These results emphasize the importance of determining the biomass yield and harvest index to develop grain yield of durum wheat, which can be used as a guide to the selection. These results are consistent with Ali (1995, Kumar and Hunshal (1998), Ali (2006) and Gashaw et al. (2007). Accordingly, we select superior genotypes in both traits in addition to the grain yield, namely, (1, 3, 5, 8 and 11) to continue to be evaluated within the program of the selection.

Table (3): Phenotypic variation and genetic parameters for studied traits in durum wheat.

\begin{tabular}{|c|c|c|c|c|c|c|c|c|c|}
\hline $\begin{array}{c}\text { Genetic } \\
\text { Parameters }\end{array}$ & $\begin{array}{c}\mathrm{PH} \\
(\mathrm{cm})\end{array}$ & $\begin{array}{c}\text { FLA } \\
\left(\mathrm{cm}^{2}\right)\end{array}$ & $\begin{array}{c}\mathrm{SL} \\
(\mathrm{cm})\end{array}$ & $\mathrm{SN} / \mathrm{m}^{2}$ & $\mathrm{G} / \mathrm{S}$ & $\begin{array}{l}1000 \\
\mathrm{GW}(\mathrm{g})\end{array}$ & $\begin{array}{c}\mathrm{BY} \\
(\mathrm{t} / \mathrm{ha})\end{array}$ & $\begin{array}{c}\mathrm{GY} \\
(\mathrm{t} / \mathrm{ha})\end{array}$ & $\begin{array}{c}\mathrm{HI} \\
(\%)\end{array}$ \\
\hline $\bar{X}$ & 88.1 & 36.25 & 6.49 & 268.6 & 33.97 & 40.45 & 11.58 & 4.29 & 0.37 \\
\hline$F$. value & $15.2^{*}$ & $1.75^{*}$ & $2.29^{*}$ & $3.1^{*}$ & $1.96^{*}$ & $9.85^{*}$ & 2.79 & $3.11^{*}$ & $2.37^{*}$ \\
\hline$\sigma^{2} G$ & $91.9^{*}$ & 7.8 & 0.16 & $1395.6^{*}$ & 6.91 & $21.0^{*}$ & $1.67^{*}$ & $0.98^{*}$ & 0.003 \\
\hline$\sigma^{2} E$ & $19.4^{*}$ & $52.3^{*}$ & $0.37^{*}$ & $1978.1^{*}$ & $21.5^{*}$ & $7.11^{*}$ & $2.80^{*}$ & $1.40^{*}$ & $0.008^{*}$ \\
\hline$\sigma^{2} P$ & $11.3^{*}$ & $60.0^{*}$ & $0.52^{*}$ & $3373.8^{*}$ & $28.5^{*}$ & $28.1^{*}$ & $4.46^{*}$ & $2.39^{*}$ & $0.01^{*}$ \\
\hline$G C V \%$ & 10.9 & 7.68 & 6.11 & 13.9 & 7.74 & 11.32 & 11.14 & 23.11 & 15.85 \\
\hline$H^{2}{ }_{\text {B.S. }}$ & 82.6 & 12.94 & 30.11 & 41.4 & 24.30 & 74.67 & 37.32 & 41.27 & 31.28 \\
\hline$E G A$ & 18.0 & 2.07 & 0.45 & 49.5 & 2.67 & 5.18 & 1.62 & 1.31 & 0.068 \\
\hline$E G A \%$ & 20.4 & 5.70 & 6.93 & 18.4 & 7.86 & 12.81 & 13.99 & 30.54 & 18.38 \\
\hline
\end{tabular}

$*=$ Significant at $5 \%$ probability level.

Table (4): Coefficients of genetic correlation between studied traits in durum wheat.

\begin{tabular}{|c|c|c|c|c|c|c|c|c|}
\hline & $\begin{array}{l}\mathrm{HI} \\
(\%)\end{array}$ & $\begin{array}{c}\text { GY } \\
(\mathrm{t} / \mathrm{ha})\end{array}$ & $\begin{array}{l}\text { BY } \\
\text { (t/ha) }\end{array}$ & $\begin{array}{c}1000 \\
\mathrm{GW}(\mathrm{g})\end{array}$ & $\mathrm{G} / \mathrm{S}$ & $\mathrm{SN} / \mathrm{m}^{2}$ & $\begin{array}{l}\mathrm{SL} \\
(\mathrm{cm})\end{array}$ & $\begin{array}{l}\text { FLA } \\
\left(\mathrm{cm}^{2}\right)\end{array}$ \\
\hline $\mathrm{PH}(\mathrm{cm})$ & 0.147 & -0.077 & $-0.582 *$ & -0.217 & -0.333 & -0.311 & 0.281 & -0.312 \\
\hline FLA $\left(\mathrm{cm}^{2}\right)$ & -0.203 & -0.241 & -0.356 & 0.056 & $0.684 *$ & $0.752 *$ & $0.443^{*}$ & \\
\hline $\mathrm{SL}(\mathrm{cm})$ & -0.094 & -0.253 & -0.309 & 0.165 & 0.232 & $-0.618^{*}$ & & \\
\hline $\mathrm{SN} / \mathrm{m}^{2}$ & -0.032 & 0.222 & $0.634^{*}$ & -0.094 & -0.312 & & & \\
\hline $\mathrm{G} / \mathrm{S}$ & 0.127 & 0.164 & 0.335 & 0.106 & & & & \\
\hline $1000 \mathrm{GW}(\mathrm{g})$ & $0.845^{*}$ & $0.849 *$ & $0.566^{*}$ & & & & & \\
\hline BY (t/ha) & $0.561 *$ & $0.776^{*}$ & & & & & & \\
\hline GY (t/ha) & $0.977 *$ & & & & & & & \\
\hline
\end{tabular}


Table (5): Direct and indirect influences of studied traits on grain yield in durum wheat.

\begin{tabular}{|c|c|c|c|c|c|c|c|c|c|}
\hline & $\begin{array}{c}\mathrm{PH} \\
(\mathrm{cm})\end{array}$ & $\begin{array}{l}\text { FLA } \\
\left(\mathrm{cm}^{2}\right)\end{array}$ & $\begin{array}{c}\mathrm{SL} \\
(\mathrm{cm})\end{array}$ & $\mathrm{SN} / \mathrm{m}^{2}$ & $\mathrm{G} / \mathrm{S}$ & $\begin{array}{c}1000 \\
\text { GW } \\
(\mathrm{g})\end{array}$ & $\begin{array}{c}\text { BY } \\
(\mathrm{t} / \mathrm{ha})\end{array}$ & $\begin{array}{l}\mathrm{HI} \\
(\%)\end{array}$ & $\begin{array}{c}\mathrm{rG} \\
\text { with } \\
\text { GY }\end{array}$ \\
\hline $\mathrm{PH}(\mathrm{cm})$ & -0.085 & -0.011 & -0.016 & 0.002 & 0.007 & 0.025 & -0.141 & 0.142 & -0.077 \\
\hline FLA $\left(\mathrm{cm}^{2}\right)$ & 0.027 & 0.034 & -0.025 & -0.004 & 0.015 & -0.006 & -0.086 & -0.196 & -0.241 \\
\hline $\mathrm{SL}(\mathrm{cm})$ & -0.024 & 0.015 & -0.057 & 0.003 & -0.005 & -0.019 & -0.075 & -0.091 & -0.253 \\
\hline $\mathrm{SN} / \mathrm{m}^{2}$ & 0.026 & 0.026 & 0.035 & $\underline{-0.005}$ & 0.007 & 0.011 & 0.153 & -0.031 & 0.222 \\
\hline $\mathrm{G} / \mathrm{S}$ & 0.028 & -0.023 & -0.013 & $\overline{0.002}$ & -0.022 & -0.012 & 0.081 & 0.123 & 0.164 \\
\hline $1000 \mathrm{GW}(\mathrm{g})$ & 0.018 & 0.002 & -0.009 & 0.0005 & $\overline{-0.002}$ & -0.116 & 0.137 & 0.816 & 0.849* \\
\hline BY (t/ha) & 0.049 & -0.012 & 0.018 & -0.003 & 0.007 & $\overline{-0.066}$ & 0.242 & 0.542 & 0.776* \\
\hline $\mathrm{HI}(\%)$ & -0.012 & -0.007 & -0.005 & 0.0002 & -0.003 & -0.098 & 0.136 & $\underline{0.966}$ & $0.977 *$ \\
\hline
\end{tabular}

$*=$ Significant at $5 \%$ probability level.

\section{Bread wheat.}

a - The performance of genotypes and phenotypic differences: Twenty genotypes of bread wheat different in all traits, as is evident from the values of $F$ given in the Table (7). (Table 6) Shows means of these genotypes in the studied traits. Genotypes 12 shows superiority in plant height $(109.67 \mathrm{~cm})$, grain yield $(4.46 \mathrm{t} / \mathrm{ha})$ and harvest index (0.44); 2 give higher flag leaf area $\left(44.33 \mathrm{~cm}^{2}\right)$ with the observation that there are many genotypes with low values in this trait, especially genotypes 1 and 2 due to sensitive to rust disease that has spread time account status. And the superiority of genotype 11 in spike length and 1000 grain weight, giving $(10.33 \mathrm{~cm})(45.13 \mathrm{~g})$, respectively, while the genotype 10 gave the highest number of spikes / $\mathrm{m}^{2}$ (345 spike), and genotype 7 in the number of grains / spike (32.33). The wide range of variation among genotypes find vary high genetically significant for all these traits (Table, 6), which is required to build effectively selection program due to these traits gave high heritability ranged between $64.42 \%$ for the spike length to $88.25 \%$ for harvest index, which led to an increase values of expected genetic advance in these traits, amounted to $(25.69,22.44,1.38,117.83$, $13.71,11.31,4.17,2.61$ and 0.19$)$ to the plant height, flag leaf area, spike length, number of spikes / $\mathrm{m}^{2}$, number of grains / spike, 1000 grain weight, biomass yield, grain yield and harvest index, respectively. These results are supported with other researchers who created a high genetic variance and genetic advance in many of the traits of the bread wheat genotypes included studies of them (Ozkan et al., 1997, Ahmed et al., 2003 and Zaeifizadeh et al., 2011).

b - Genetic correlation and path coefficient analysis: Values of genetic correlation coefficients between traits presented in Table (8) that was positive and significant between all traits except between plant height and number of grains / spike and between spike length and number of spikes $/ \mathrm{m}^{2}$, although these positive results make it easier for plant breeders to build the effective selection, but these correlations alone is not sufficient and the guarantor to achieve that, therefore, has been introduced in the path coefficient analysis which provides an effective way of finding out direct and indirect sources of correlations by using genotypic into direct 
and indirect effects to identify statistically the most important traits of a direct effect and this is was actually from the data presented in Table (9), where it is

Table (6) Mean of the studied traits in bread wheat genotypes.

\begin{tabular}{|c|c|c|c|c|c|c|c|c|c|}
\hline Genotypes & $\begin{array}{c}\text { PH } \\
(\mathrm{cm})\end{array}$ & $\begin{array}{c}\text { FLA } \\
\left(\mathrm{cm}^{2}\right)\end{array}$ & $\begin{array}{c}\text { SL } \\
(\mathrm{cm})\end{array}$ & SN/m & G/S & $\begin{array}{l}1000 \\
\text { GW(g) }\end{array}$ & $\begin{array}{c}\text { BY } \\
(\mathrm{t} / \mathrm{ha})\end{array}$ & $\begin{array}{c}\text { GY } \\
(\mathrm{t} / \mathrm{ha})\end{array}$ & $\begin{array}{c}\mathrm{HI} \\
(\%)\end{array}$ \\
\hline 1 & 95 & 3 & 8 & 187 & 8.33 & 27.73 & 4.41 & 0.58 & 0.13 \\
\hline 2 & 51.33 & 0 & 7.67 & 44 & 5.67 & 15.33 & 2.87 & 0.27 & 0.09 \\
\hline 3 & 97.67 & 4.67 & 8.33 & 200 & 11 & 30.4 & 3.80 & 0.70 & 0.19 \\
\hline 4 & 94 & 26.33 & 7 & 328 & 12.67 & 36.3 & 6.38 & 1.68 & 0.26 \\
\hline 5 & 84.67 & 26.67 & 8.33 & 131.33 & 14.67 & 36.03 & 4.36 & 0.88 & 0.20 \\
\hline 6 & 99.33 & 7.67 & 8.33 & 268.33 & 12.67 & 30.4 & 5.5 & 1.43 & 0.27 \\
\hline 7 & 79.33 & 26.67 & 9.33 & 271 & 32.33 & 26.17 & 8.97 & 3.31 & 0.37 \\
\hline 8 & 102.33 & 13.67 & 7.67 & 321.67 & 11.67 & 34.83 & 6.01 & 1.5 & 0.25 \\
\hline 9 & 98.33 & 27 & 8.33 & 299 & 15.33 & 37.07 & 7.14 & 2.12 & 0.30 \\
\hline 10 & 99.33 & 5.67 & 9 & 345 & 12.33 & 29.17 & 6.19 & 1.34 & 0.22 \\
\hline 11 & 102.33 & 33.67 & 10.33 & 268.33 & 24.67 & 45.13 & 9.37 & 4.16 & 0.44 \\
\hline 12 & 109.67 & 27.33 & 9.67 & 305 & 23 & 43.03 & 10.24 & 4.46 & 0.44 \\
\hline 13 & 109 & 30.33 & 10 & 280.33 & 25.67 & 41.7 & 9.64 & 4.14 & 0.43 \\
\hline 14 & 109 & 36.67 & 9.33 & 341 & 20.67 & 33.1 & 9.13 & 3.02 & 0.33 \\
\hline 15 & 109.33 & 44.33 & 9.33 & 329.33 & 23 & 34.9 & 10.2 & 2.9 & 0.29 \\
\hline 16 & 91.33 & 28.33 & 10 & 265 & 19 & 33.33 & 7.37 & 1.96 & 0.27 \\
\hline 17 & 107.33 & 32 & 10 & 299.67 & 24 & 41.37 & 9.24 & 4.03 & 0.44 \\
\hline 18 & 104 & 33.33 & 9.33 & 255.33 & 14 & 33.13 & 6.75 & 2.11 & 0.31 \\
\hline 19 & 85.33 & 28 & 8.67 & 281 & 17.33 & 30.67 & 7.44 & 1.27 & 0.18 \\
\hline 20 & 81.67 & 35 & 8.67 & 325 & 32 & 30.63 & 9.61 & 3.71 & 0.39 \\
\hline LSD (5\%) & $\mathbf{9 . 7 4}$ & $\mathbf{1 0 . 6 1}$ & $\mathbf{1 . 0 2}$ & $\mathbf{8 0 . 7 1}$ & $\mathbf{5 . 0 6}$ & $\mathbf{6 . 0 8}$ & $\mathbf{1 . 5 4}$ & $\mathbf{0 . 6 1}$ & $\mathbf{0 . 0 7}$ \\
\hline
\end{tabular}

$\mathrm{PH}=$ Plant height; FLA = Flag leaf area; $\mathrm{SL}=$ Spike length; $\mathrm{SN} / \mathrm{m}^{2} ; \mathrm{G} / \mathrm{S}=$ Number of grains/spike; $1000 \mathrm{GW}=1000$ grain weight; $\mathrm{By}=$ Biomass yield; $\mathrm{GY}=$ Grain yield; $\mathrm{HI}=$ Harvest index.

noted that the higher positive genetic correlation between harvest index and grain yield created a positive direct effect for the harvest index on grain yield, but all its indirect effects via other traits were negative or weak, as it did not show any trait a positive direct effect among the other traits that are relevant to the positive correlation with the grain yield except flag leaf area (0.352) with the negative or weak direct effects of other, and this confirms as we went in the past is no need to be positive genetic between any trait and grain yield have a positive direct effect on the grain yield, as is evident in many of the traits that were have a positive genetic correlation with grain yield in bread wheat, but it had the negative direct effects. On the other hand it was showed that all traits had a high positive indirect effects via harvest index only, while all other effects were negative or weak. This shows clearly the maximum relative importance of the harvest index in determining high grain yield in bread wheat and confirms this, too, that the genotypes superior in harvest index were superior in the grain yield as well (Table, 7), which is can be used as an selection index between genotypes, This is created by Sharma (1993), 
Table (7): Phenotypic variation and genetic parameters for studied traits in bread wheat.

\begin{tabular}{|c|c|c|c|c|c|c|c|c|c|}
\hline $\begin{array}{c}\text { Genetic } \\
\text { parameters }\end{array}$ & $\begin{array}{c}\mathrm{PH} \\
(\mathrm{cm})\end{array}$ & $\begin{array}{c}\text { FLA } \\
\left(\mathrm{cm}^{2}\right)\end{array}$ & $\begin{array}{c}\mathrm{SL} \\
(\mathrm{cm})\end{array}$ & $\mathrm{SN} / \mathrm{m}^{2}$ & $\mathrm{G} / \mathrm{S}$ & $\begin{array}{c}1000 \\
\mathrm{GW}(\mathrm{g})\end{array}$ & $\begin{array}{c}\mathrm{BY} \\
(\mathrm{t} / \mathrm{ha})\end{array}$ & $\begin{array}{c}\mathrm{GY} \\
(\mathrm{t} / \mathrm{ha})\end{array}$ & $\begin{array}{c}\mathrm{HI} \\
(\%)\end{array}$ \\
\hline $\bar{X}$ & 95.5 & 23.52 & 8.87 & 267.27 & 18 & 33.52 & 7.23 & 2.28 & 0.29 \\
\hline$F$. value & $16.6^{*}$ & $11.78^{*}$ & $6.43^{*}$ & $7.01^{*}$ & $17.36^{*}$ & $9.75^{*}$ & $17.35^{*}$ & $38.55^{*}$ & $23.52^{*}$ \\
\hline$\sigma^{2} G$ & $185.4^{*}$ & $151.7^{*}$ & $0.71^{*}$ & $4901.9^{*}$ & $52.43^{*}$ & $40.51^{*}$ & $4.86^{*}$ & $1.74^{*}$ & $0.010^{*}$ \\
\hline$\sigma^{2} E$ & $35.58^{*}$ & $42.22^{*}$ & $0.39^{*}$ & $2443.0^{*}$ & $9.61^{*}$ & $13.88^{*}$ & $0.89^{*}$ & $0.14^{*}$ & $0.002^{*}$ \\
\hline$\sigma^{2} P$ & $221.0^{*}$ & $193.9^{*}$ & $1.09^{*}$ & $7344.9^{*}$ & $62.05^{*}$ & $54.39^{*}$ & $5.75^{*}$ & $1.88^{*}$ & $0.012^{*}$ \\
\hline$G C V \%$ & 14.26 & 52.38 & 9.47 & 26.20 & 4023 & 18.99 & 30.48 & 57.95 & 35.20 \\
\hline$H^{2}{ }_{\text {B.S. }}$ & 83.90 & 78.23 & 64.42 & 66.74 & 84.50 & 74.48 & 84.50 & 92.60 & 88.25 \\
\hline$E G A$ & 25.69 & 22.44 & 1.38 & 117.83 & 13.71 & 11.31 & 4.17 & 2.61 & 0.19 \\
\hline$E G A \%$ & 26.90 & 95.43 & 15.66 & 44.09 & 76.18 & 33.76 & 57.73 & 114.87 & 68.11 \\
\hline
\end{tabular}

$*=$ Significant at $5 \%$ probability level.

Table (8): Coefficients of genetic correlation between studied traits in bread wheat.

\begin{tabular}{|c|c|c|c|c|c|c|c|c|}
\hline & $\begin{array}{l}\mathrm{HI} \\
(\%)\end{array}$ & $\begin{array}{l}\text { GY } \\
\text { (t/ha) }\end{array}$ & $\begin{array}{l}\text { BY } \\
\text { (t/ha) }\end{array}$ & $\begin{array}{l}1000 \\
\text { GW (g) }\end{array}$ & $\mathrm{G} / \mathrm{S}$ & $\mathrm{SN} / \mathrm{m}^{2}$ & $\begin{array}{l}\text { SL } \\
(\mathrm{cm})\end{array}$ & $\begin{array}{l}\text { FLA } \\
\left(\mathrm{cm}^{2}\right)\end{array}$ \\
\hline $\mathrm{PH}(\mathrm{cm})$ & $0.556^{*}$ & $0.501^{*}$ & $0.554 *$ & $0.845^{*}$ & 0.221 & $0.773 *$ & $0.546^{*}$ & $0.447 *$ \\
\hline FLA $\left(\mathrm{cm}^{2}\right)$ & $0.715^{*}$ & $0.761 *$ & $0.899 *$ & $0.640 *$ & $0.785^{*}$ & $0.575^{*}$ & $0.629 *$ & \\
\hline $\mathrm{SL}(\mathrm{cm})$ & $0.798^{*}$ & $0.801 *$ & $0.758 *$ & $0.632 *$ & $0.688^{*}$ & 0.334 & & \\
\hline $\mathrm{SN} / \mathrm{m}^{2}$ & $0.598 *$ & $0.564 *$ & $0.739 *$ & $0.551 *$ & $0.535^{*}$ & & & \\
\hline $\mathrm{G} / \mathrm{S}$ & $0.877^{*}$ & $0.902 *$ & $0.913^{*}$ & $0.467 *$ & & & & \\
\hline $1000 \mathrm{~W}(\mathrm{~g})$ & $0.760^{*}$ & $0.705^{*}$ & $0.668 *$ & & & & & \\
\hline BY (t/ha) & $0.921 *$ & $0.948^{*}$ & & & & & & \\
\hline GY (t/ha) & $0.988 *$ & & & & & & & \\
\hline
\end{tabular}

$*=$ Significant at $5 \%$ probability level.

Table (9): Direct and indirect influences of studied traits on grain yield in bread wheat.

\begin{tabular}{|l|c|c|c|c|c|c|c|c|c|}
\hline & $\begin{array}{c}\text { PH } \\
(\mathrm{cm})\end{array}$ & $\begin{array}{c}\text { FLA } \\
\left(\mathrm{cm}^{2}\right)\end{array}$ & $\begin{array}{c}\mathrm{SL} \\
(\mathrm{cm})\end{array}$ & $\mathrm{SN} / \mathrm{m}^{2}$ & $\mathrm{G} / \mathrm{S}$ & $\begin{array}{c}1000 \\
\mathrm{GW} \\
(\mathrm{g})\end{array}$ & $\begin{array}{c}\mathrm{BY} \\
(\mathrm{t} / \mathrm{ha})\end{array}$ & $\begin{array}{c}\text { HI } \\
(\%)\end{array}$ & $\begin{array}{c}\text { rG } \\
\text { with } \\
\mathrm{GY}\end{array}$ \\
\hline $\mathrm{PH}(\mathrm{cm})$ & $\underline{\mathbf{0 . 1 5 2}}$ & 0.157 & 0.039 & 0.065 & -0.096 & -0.232 & -0.068 & 0.788 & $\mathbf{0 . 5 0 1}^{*}$ \\
\hline FLA $\left(\mathrm{cm}^{2}\right)$ & -0.068 & $\underline{\mathbf{0 . 3 5 2}}$ & 0.045 & 0.048 & -0.343 & -0.175 & -0.111 & 1.013 & $\mathbf{0 . 7 6 1}$ \\
\hline $\mathrm{SL}(\mathrm{cm})$ & -0.083 & 0.221 & $\underline{0.071}$ & 0.028 & -0.301 & -0.173 & -0.093 & 1.131 & $\mathbf{0 . 8 0 1}$ \\
\hline $\mathrm{SN} / \mathrm{m}^{2}$ & -0.117 & 0.202 & 0.024 & $\underline{\mathbf{0 . 0 8 4}}$ & -0.234 & -0.151 & -0.091 & 0.847 & $\mathbf{0 . 5 6 4}^{*}$ \\
\hline $\mathrm{G} / \mathrm{S}$ & -0.024 & 0.276 & 0.049 & 0.045 & $\underline{\mathbf{- 0 . 4 3 7}}$ & -0.128 & -0.112 & 1.243 & $\mathbf{0 . 9 0 2}^{*}$ \\
\hline $1000 \mathrm{GW}(\mathrm{g})$ & -0.128 & 0.225 & 0.045 & 0.046 & 0.204 & $\underline{\mathbf{- 0 . 2 7 4}}$ & -0.082 & 1.077 & $\mathbf{0 . 7 0 5}$ \\
\hline $\mathrm{BY}(\mathrm{t} / \mathrm{ha})$ & -0.084 & 0.316 & 0.054 & 0.062 & -0.399 & -0.183 & $\underline{\mathbf{- 0 . 1 2 3}}$ & 1.305 & $\mathbf{0 . 9 4 8}^{*}$ \\
\hline HI $(\%)$ & -0.085 & 0.252 & 0.057 & 0.051 & -0.383 & -0.208 & -0.113 & $\underline{\mathbf{1 . 4 1 7}}$ & $\mathbf{0 . 9 8 8}^{*}$ \\
\hline
\end{tabular}

- = Significant at $5 \%$ probability level.

Ali (1995) and Khayatnezhad et al. (2010). Accordingly, we can select genotypes $(7,11,12,13$ and 17) to continue to be evaluated in the program of the forthcoming selection. It is necessary to note that plant breeders looking usually for the traits 
with a direct effect, but it is important to have these traits with a positive genetic correlation with grain yield to ensure the achievement of genetic improvement in the grain yield when relied upon as a criterion for selection, or it has to be depend on hybridization program, in addition to the need of these traits highly inherited in two sets of durum and bread wheat contained in this study.

$$
\begin{aligned}
& \text { التوريث والتباين والارتباط الوراثي وتحليل المسارللصفات الكمية }
\end{aligned}
$$

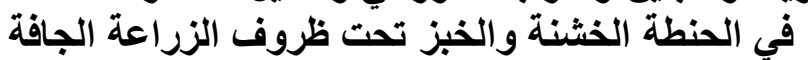

$$
\begin{aligned}
& \text { عرفان فاتح شكور } \\
& \text { مديرية البحوث الزراعية / أربيل }
\end{aligned}
$$

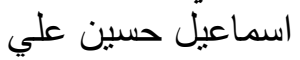

$$
\begin{aligned}
& \text { كلية الزر اعة / جامعة صلاع الدين / أربين }
\end{aligned}
$$

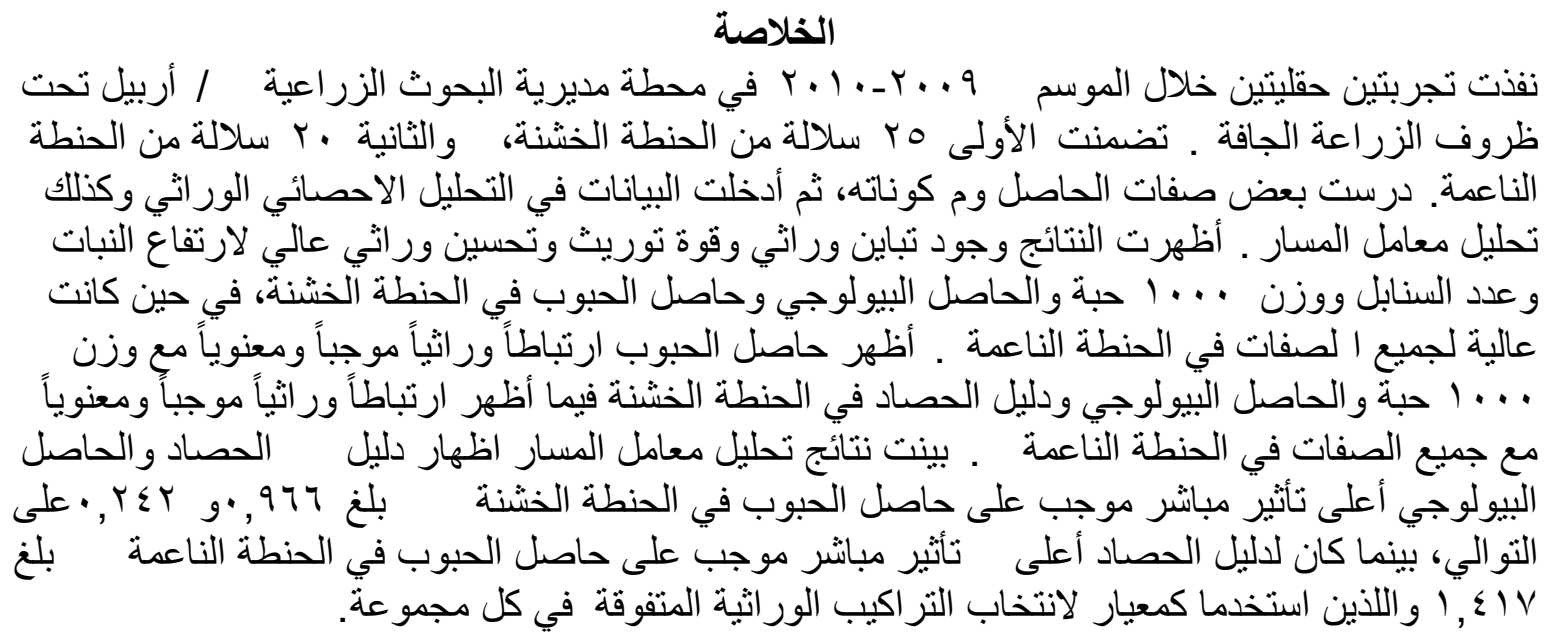

\section{REFERENCES}

Ahmed, H. M., B. M. Khan, S. Khan, N. S. Kissana and S. Laghari (2003). Path coefficient analysis in bread wheat. Asian. J. Plant Sci., 2(6): 491-494.

Ali, I. H. (1995). Genetic analysis of some quantitative trait in wheat under limited rainfed conditions. Mesopotamia Agric. J. 27 (2): 108-112.

Ali, I. H. (2006). Genetic analysis of diallel crosses in $F_{1}$ and $F_{2}$ generations and selection in durum wheat. Ph.D. thesis, Plant Production Dept. College of Agric., Univ. of Salahaddin.

Bhutta, W. M., J. Akhtar, M. A. Ibrahim (2005). Cause and effect relations of yield components in spring wheat (Triticum aestivum L.) under normal conditions. Caderno de Pesquisa serie Biologia, 17:7-12.

Dewey, D. R. and K. H. Lu (1959) . A correlation and path- coefficient analysis of components of crested wheatgrass seed production. Agron. J., 51(8): 515518.

Fisher, R. A., J. H. Lindt and A. Glave (1977). Irrigation of dwarf wheat's in the Yaqui Valley of Mexico. Experimental Agric., 13(4): 353-367.

Garcia del Moral, L. F., Y. Rharrabti, D. Villegas and C. Royo (2003). Evaluation of grain yield and its components in durum wheat under mediterranean conditions. Agron. J., 95:266-274. 
Gashaw, A., H. Mohammed and H. Singh (2007). Selection criterion for improved grain yields in ethiopian durum wheat genotypes. Afric. Crop Sci. J., 15(1): $25-31$.

Hochman, Z. (1982). Effect of water stress with phasic development on yield of wheat grown in a semi-arid environment. Field Crops Res., 5(1): 55-67.

Kempthoren, O. (1969). An Introduction to Genetic Statistics. Ames, Iowa State Univ., Press, USA.

Khayatnezhad, M., M. Zaefizadeh, R. Ghoamin and S. Jamaati-e-Somarin (2010). Study of genetic diversity and path analysis for yield in durum wheat genotypes under water and dry conditions. World Appl. Sci. J., 9(6): 655665.

Kumar, A. B. N. and C. S. Hunshal (1998). Correlation and path coefficient analysis in durum wheat's (Triticum durum Desf.) under different planting. Crop Research Hisa, 16(3): 358-361.

Mather, K. and J. L. Jinks. (1977). Introduction to Biometrical Genetics. Chapman and Hall, London, UK.

McMaster, G. C., W. W. Wilhelm and P. N. S. Bartling (1984). Irrigation and culm contribution to yield and yield components of winter wheat. Agron. J., 86(6): 1123-1127.

Nofouzi, F., V. Rashidi and A. R.Tarinejad (2008). Path Analysis of Grain Yield with Its Components in Durum Wheat under Drought Stress. International Meeting on Soil Fertility Land Management and Agroclimatology. Turkey, p: 681-686.

Okuyama, L.A., L. C. Federizzi and J. F. B. Neto (2004). Correlation and path analysis of yield and its components and plant traits in wheat.Cienc. Rural., 34(6): 1701-1708.

Ozkan, H., T. Yagbasanlar and I. Genc (1997). Genetic analysis of yield components, harvest index and biological yield in bread wheat under Mediterranean climatic conditions. Rachis, 49-52.

Poehlman, J. M. (1987). Breeding Field Crops. 3rd ${ }^{\text {ed }}$. Published by Van nostrand Reinhold, New York, USA.

Sharma, R. C. (1993). Selection for biomass yield in wheat. Euphytica, 70:3542.

Simane, B., P. C. Struik and R. Pabbinge (1998). Growth and yield component analysis of durum wheat as an index of selection to terminal moisture stress. Tropical Agric., 75(3): 363- 368.

Simane, B., P. C. Struik, M. M. NachitandJ. and M. Peacock (1993). Ontogenetic analysis of yield components and yield stability of durum wheat in waterlimited environments. Euphytica, 71(3):211-219.

Sinha, B. C., S. N. Ral and B. C. Seha (1984). Correlation and path analysis in an advanced generation of wheat. (Triticum aestivum L.). Genetika,16: 131138.

Talebi, R., F. Fayyaz and A. M. Naji (2011). Genetic variation and interrelationships of agronomic traitistics in durum wheat under two constructing water regimes. Braz. Arch. Biol. Technol., 53(4): 785-791. 
$\begin{array}{ll}\text { Mesoptamia J. of Agri } \quad \text { ISSN: } 2224-9796 \text { (Online) } & \text { Vol. ( } 40 \text { ) No.( } 4 \text { )2012 }\end{array}$

Thomas, H. (1975). The growth response to weather of simulated vegetative swards of a single genotype of lolium perenne. J. Agric. Sci., 84:333-343.

Thompson, J. A. and D. L. Chase (1992). Effect of limited irrigation on growth and yield of a semi-dwarf wheat in southern New South Wales. Australian J. of Experimental Agric., 32: 725-730.

Walter, A. B. (1975). Manual of Quantitative Genetics. $3^{\text {rd }}$ ed. Washington State Univ. USA.

Yagdi, K. (2009). Path coefficient analysis of some yield components in durum wheat (Triticum durum Desf.). Pak. J. Bot., 41(2): 745-751.

Zaeifizadeh, M., M. Khayatnezhad, M. Ghasemi, J. Azimi and M. Vahabzadeh (2011). Path analysis of yield and yield components in synthetic bread wheat (Triticum aestivum L.) genotypes. Adv. Environ. Biol., 5(1): 98-103. 